\title{
The Effect of Lubuk Larangan on Environmental Knowledge for the Topic of River Ecosystem of Community and Students in Padang Lawas Utara Regency
}

\author{
Berliani Ritonga ${ }^{1)}$, Syarifuddin ${ }^{2}$, Tumiur Gultom ${ }^{3)}$ \\ ${ }^{1}$ Berliani Ritonga, Student of Postgraduate Program of Biology Education, Universitas Negeri Medan Indonesia \\ ${ }^{2}$ Syarifuddin, Lecturer of Postgraduate Program of Biology Education, Universitas Negeri Medan \\ ${ }^{3}$ Tumiur Gultom, Lecturer of Postgraduate Program of Biology Education, Universitas Negeri Medan \\ email: berliani_ritonga@yahoo.co.id
}

\begin{abstract}
The purpose of this study was to determine the effect of lubuk larangan on community's and students' environmental knowledge based on: (1) school location; (2) gender perspective; and (3) the level of education for the topic of river ecosystem in Padang Lawas Utara Regency. The study was a quantitative descriptive research methods, direct observation or interviews. The sample of 252 participants was determined by purposive sampling technique. The knowledge test was 10 questions. The data analysis technique was employed by MannWhitney and Kruskal Wallis Tests. The results showed that: (1) there was a significant effect on environmental knowledge based on school location $(U=6144,500 ; P=0.002)$. The knowledge of closer lubuk larangan was $65.20 \pm 15.994(X \pm S B)$; higher than that of further lubuk larangan was $57.01 \pm 20.288(X \pm S B) ;(2)$ there was a significant effect on environmental knowledge based on gender perspective $(U=6353,000 ; P=0.014)$. Male's knowledge was $64.25 \pm 18.667(\mathrm{X} \pm \mathrm{SB})$ higher than that of female's was $58.77 \pm 18.454(X \pm \mathrm{SB})$; (3) there was a significant effect on environmental knowledge based on the level of education $(2=17,875 ; P=0,000)$. Community's knowledge was $71.25 \pm 15,053(X \pm$ SB $)$ higher than Senior High School's students knowledge was $64,00 \pm 15,916(X \pm S B)$ higher than Junior High School's students knowledge was 62,46 \pm 17,680 (X \pm SB) and higher than Elementry School's students knowledge was $51,95 \pm 19,937(X \pm S B)$. Follow-up research is expected to the government, parents, teachers, and other sources of information for always preserving lubuk larangan as local wisdom for the knowledge of society and students who can improve their living welfare.
\end{abstract}

Keywords - lubuk larangan, environmental knowledge, river ecosystem

\section{INTRODUCTION}

Environmental education in schools is not specifically available in the Curriculum 2013 or the previous curriculum. Considering that environmental damage in Indonesia is still massive, environmental education should have an important portion in the curriculum starting from elementary school to college. Due to the very lack of aspects of environmental education in the curriculum, it is not surprising that the community at large is still lacking in paying attention to the environment. There are still many community members who throw garbage litterily, consciously or not polluting rivers and other water bodies. Likewise with the destruction of other environmental aspects. The low environmental awareness of the large number of community members has resulted from the lack of knowledge about the environment.

These conditions have an impact on science learning, which shows that there are still many scientific learning processes that are carried out using conventional methods. The tendency that often occurs that learning activities are less focused on developing student science process skills. In the end, science learning activities were carried out only focused on delivering material in textbooks. The priority should be on how to develop a sense of curiosity and one's thinking power towards a problem (Marjono in Susanto, 2013).

Conservation of the environment as an effort to create a natural environment that is sufficient quantity and quality for the present generation and the next generation that involves many parties including indigenous peoples who have existed for a long time and have cultural peculiarities. Various parties involved basically have one goal, namely to achieve economic, social and ecological balance.

In addition to the low role of formal education institutions as well as weak environmental law enforcement in Indonesia it turns out that in some regions there are local wisdoms that are far from cities that play a role in protecting the environment. Lubuk larangan, for example, which is widely found in the South Tapanuli Region, such as Lubuk Larangan Desa Rocitan, one of the areas that preserve the lubuk larangan is the community of Madina District, Tambangan Regency, named Lubuk Larangan Anak Yatim (Hidayah, 2016), and several places in West Sumatra. Lubuk larangan is an attempt by community groups, or indigenous people to preserve certain parts of the river, especially fish contained in it. With lubuk larangan generally all members of the community are obedient to maintain the sustainability of the river where the community is not allowed to take fish and litter. Fish harvesting can be done once a year with mutual agreement in the community.

Indonesia's wealth of local wisdom has existed since the past ancestors., only its implementation has been increasingly 
imbued by changes in times and foreign cultural influences. Local wisdom should not only be seen as a beautiful mosaic but can be used as a force to be able to carry out development in harmony and harmony with nature. Community groups in environmental adaptation develop social capital to manage the environment, such as knowledge, environmental ethics, values, norms, folklore, traditions, and religious rituals. Environmental wisdom is very meaningful and closely related to cultural institutions, especially institutions of belief (religion), social organization, kinship and law (customs). Local wisdom on the environment is currently undergoing a process of elimination marked by changes in social order, reduced human values, reduced community independence, poverty in environmental ethics supporting human life. In addition, local wisdom that is full of moral values must not be removed simply because it is considered unreasonable and cannot be explained scientifically. Local wisdom can be realized in various aspects of life both directly and indirectly. Local wisdom can develop in everyday life through example and teachings from parents to their children and grandmother to their grandchildren (Saam, 2012).

A number of studies on the lubuk larangan that have been carried out in Sumatra vary in aspects of culture (local myths, village consensus deliberations, joint harvesting times, fishing catching areas), economics (increasing community economic resources, village treasury, building mosques, village reserve funds), conservation management (not littering, spreading fish seeds, protecting the environment in the prohibition with applicable regulations), as well as the level of fish diversity, but no one has examined the influence of the prohibition on environmental knowledge levels. Hidayah et al (2016), which showed the level of education influences the level of knowledge about the environment based on the local wisom of Lubuk Larangan in Tambangan Jae Village, Tambangan District, Madina Regency. Community knowledge is higher than senior high school, junior high school and elementary school students. The effect of the lubuk larangan on the level of environmental knowledge based on school location is stated that the ones who are close to lubuk larangan is higher than the students whose schools are far from lubuk larangan. This means that the existence of lubuk larangan also has a positive impact on the level of knowledge so that the awareness of the environment of students and surrounding people can improve well.

The results of the average score for the final semester of science or biology exams achieved by students were still less than the Minimal Accomplishment Criteria set by each school. The average value of SDN Sidingkat Aek Sigama was class VI of 72, SMPN 1 Padang Bolak of 74, and SMAN 2 Padang Bolak of 74 from KKM 75 in Padang Lawas Utara Regency in the Academic Year 2016/2017. Students' science learning outcomes are still relatively low which are influenced by many factors. A very important factor is the student learning environment in the form of strategies created by teachers to optimize the potential of students in learning and using the concept of science in understanding the environment. Although theoretically the science learning paradigm is directed towards constructivism or building, in reality the teacher still prefers to use the lecture method in front of the class (Wisudawati \& Sulistiyowati, 2014).

Observations from researchers in each school found that science learning activities were dominated by teacher centered methods. The method of discussion and experimentation was rarely done for students but only hears and notes so students feel that science is a less fun lesson because it is full of concepts of submission. This was consistent with the results of the initial observations to these schools which were seen in accordance with the facts on the ground. This fact indicated that students' environmental knowledge was still low.

Based on this data that participation in the maintenance or preservation of the community and students' environment is still relatively low. Realizing this, this problem is further examined through a study of variables that can influence the local wisdom of lubuk larangan on knowledge so that the surrounding environment can be preserved and preserved throughout time. The deterioration of environmental quality is caused by the depletion of natural resources and the emergence of various environmental problems that can be caused by a lack of knowledge about the environment, which causes environmental damage. A person responds to nature as a teacher who gives a reference to people's lifestyles, who are born in the form of natural habits that are poured into life customs that are oriented to the developed natural attitude of being a teacher (Salim, 2006).

The establishment of a prohibition is because lubuk larangan is a hereditary culture from our predecessors that must be preserved. This is seen by thousands of fish growing in the Batang Pane river which stretches in their village like tilapia, crisp, jurung-jurung. The fish play loose in the water with residents who bathe in the river. It is evident that the people's efforts to protect the surrounding natural ecosystems, especially the Sibagasi River which is a source of livelihood for the people. The Sibagasi Village Chief said that the purpose of establishing a prohibition was to use the river to exploit the results which were used for building mosques and typical villages. The village which has owned lubuk larangan means that it has preserved the village's culture and environment. In addition, the village has also carried out customs, including customary law for violations of taking fish in the bottom. Various village regulations and customary law were made, so that the survival of the ecosystem occurred in the prohibition.

To overcome environmental problems for the realization of the concept of sustainable development, the government must provide a forum to increase the knowledge of students and the community about the environment through the role of extension workers so that they always participate actively in environmental preservation. Therefore, it is necessary to solve problems in the context of the knowledge of students and the community about the environment on river ecosystems with the existence of natural learning using the location of lubuk larangan in Padang Lawas Utara District. 


\section{RESEARCH METHOD}

\section{A. Location and Time of the Study}

The study was conducted at SDN Pagaran Tonga and Sidingkat Aek Sigama, Padang Bolak State Middle School and High School and the community in Padang Lawas Utara Regency. The study was conducted from May to July 2017.

\section{B. Population and Sample of the Study}

The population was all sixth grade students of elementary school, class VII of junior high school, and class X of high school and community. Sampling based on the population was carried out by purposive sampling of both the population near and far from lubuk larangan. Samples taken from each school amounted to 1 class and 20 people each from the close community $(2 \mathrm{~km})$ and far $(40 \mathrm{~km})$ from lubuk larangan. So the total sample of students and community research was 252 people.

\section{Type and Design of the Research}

The type of research was a quantitative descriptive which aims to obtain data according to the characteristics based on the numbers obtained as it is in the form of an average level of knowledge from the community and students' environmental knowledge. Collecting data or information from a community group and students through observation or direct interviews. Obtaining information about the actual state of environmental knowledge in Padang Lawas Utara District.

\section{Instruments of Data Collection}

Data collection techniques used were direct observation or interviews and environmental knowledge tests. Interviews were carried out to village heads as village leaders, two representatives from the lubuk larangan committee, and eight people in Padang Lawas Utara, South Tapanuli and West Pasaman Districts. Direct observation was employed by documenting the lubuk larangan.

The community and students' environmental knowledge test instrument was used as many as 6 multiple choice questions and 4 questions so the total knowledge test was 10 questions. Before being used as a data collection instrument, this instrument was first validated by professional validators, that were Biology Lecturers of Universitas Negeri Medan.

\section{E. Technique of Data Analysis}

Data analysis techniques were a quantitative descriptive analysis of mean, value median value, minimum value, maximum value, and standard deviation. Then the prerequisite test applied the normality and homogeneity tests. Research hypothesis testing used the Mann-Whitney and Kruskal Wallis tests with Wilcoxon. Data processing was analyzed using the SPSS program application (Statistical Package for Social Sciences).

\section{RESULTS}

\section{A. Results Description Lubuk Prohibition}

The results of the research data were scores of environmental knowledge from the community and students based on school location, gender perspective, and the status or level of education in Padang Lawas Utara Regency. The results of interviews or direct observations in the form of documentation of lubuk prohibitions were obtained from Padang Lawas Utara, South Tapanuli and West Pasaman Regencies.

The description of Sipalanduk's Lubuk Larangan in Padang Lawas Utara Regency has a river depth of $1 \frac{1}{2}$ meters with a width of 30 meters. The environment of the lubuk larangan is quite clean, the condition of the water is clear and calm, the river body of the hole is straight, there are small rocks. There are catfish, red, limbat and other fish that come from the river because it has mixed and the amount of harvest varies from $1 \mathrm{~kg}$ in one fish to $3 \mathrm{~kg}$. The benefits of fish harvesting as typical or village's savings. The existence of lubuk larangan teaches the young generation on how to maintain river fish habitat well because this can provide benefits for the welfare of citizens.

The description of the Raniate's Lubuk Larangan in South Tapanuli Regency there is a mystical ban, if the fish in the hole is eaten, it will die. There is a lot of waste in the form of bins in the form of plastic, turbid and calm water conditions, the lubuk larangan are turning down and there are no rocks. There are jurung-jurung fish with an estimated weight of $1 \mathrm{~kg}$.

The description of the ground of the Landua's Lubuk Larangan in West Pasaman Regency has a river depth of 1 meter with a width of 15 meters. There is a lot of waste in the form of plastic in the form of plastic, water conditions are clearer and richer, the river body is a straight hole, there is a large mamak stone. The lubuk larangan has jurung-jurung fish with an estimated weight of $5 \mathrm{~kg}$. The advantages of lubuk larangan in terms of ecotourism, the profits of which are used for village needs so that the community cares about the environment with the existence of a prohibition.

\section{B. Knowledge Level Based on School Location}

The level of community and students' environmental knowledge about the river ecosystem in Lubuk Larangan was analyzed based on the location of the respondents who are close $(\mathrm{N}=125)$ and far from the bottom of the prohibition $(\mathrm{N}$ $=127$ ). The data located near from lubuk lubuk larangan was obtained by the average value and the standard deviation was $65.20 \pm 15.994$, and the data was not normally distributed $(\mathrm{Z}=$ $0.186 ; \mathrm{P}=0.000)$. Meanwhile, the acquisition of values located far from lubuk larangan with the average and standard 
deviation was $57.01 \pm 20.288$, and the data was not normally distributed $(\mathrm{Z}=0.164 ; \mathrm{P}=0.000)$.

The homogeneity test results showed the variation of data between sample groups in the population was not homogeneous $(\mathrm{F}=7.517 ; \mathrm{P}=0.007)$. Analysis with the MannWhitney test showed that the location of the respondent's school that was close and far from lubuk larangan affected the level of the community and students' knowledge $(\mathrm{U}=$ $6144,500 ; \mathrm{P}=0.002)$.

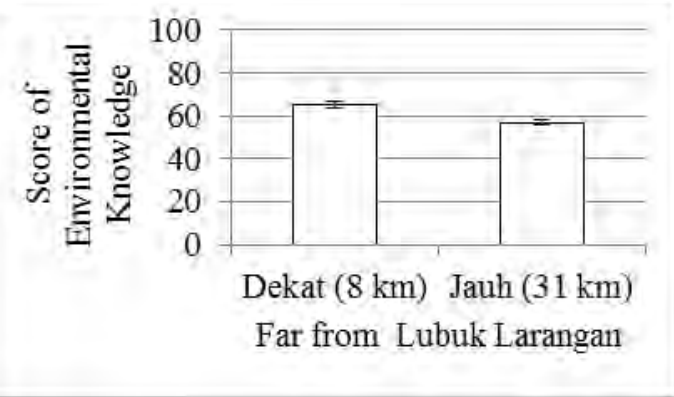

Fig 1. The Effect of Lubuk Larangan on Community and Students' Knowledge Based on School Locations in Padang Lawas Utara Regency ( $\mathrm{P}=$ 0.002 )

\section{Knowledge Level Based on Gender Perspective}

The level of community and students' environmental knowledge based on the gender perspective of 146 female respondents and 106 males showed that the acquisition of women's scores with average and standard deviation was $58.77 \pm 18.454$, and the data was not normally distributed $(\mathrm{Z}=$ $0.153 ; \mathrm{P}=0,000)$. Whereas men, the average value and standard deviation was $64.25 \pm 18.667$, and the data was not normally distributed $(\mathrm{Z}=0.215 ; \mathrm{P}=0.000)$.

The homogeneity test results showed the variation of data between sample groups in a homogeneous population $(\mathrm{F}=$ $0.214 ; \mathrm{P}=0.644)$. Analysis with the Mann-Whitney test which showed that the gender perspective of respondents influenced the level of knowledge of the river ecosystem in lubuk larangan $(\mathrm{U}=6353,000 ; \mathrm{P}=0.014)$.

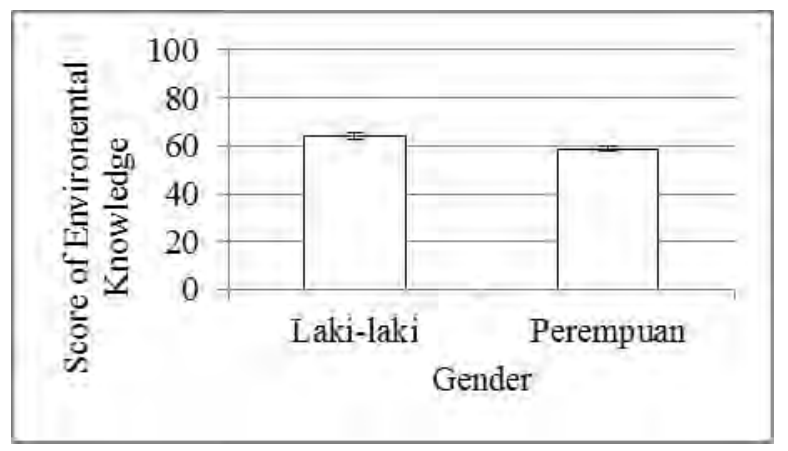

Fig 2. The Effect of Lubuk Larangan on Community and Students' Knowledge Based on Gender Perspective in Padang Lawas Utara Regency (P $=0.014$ )

\section{Knowledge Level Based on the Status or Level of Education}

The level of knowledge of the community and students' environment about the river ecosystem in lubuk larangan were four categories of levels of education, namely community, elementary, junior and senior high school. A total of 40 were in the community category, with the acquisition of the mean and standard deviation was $71.25 \pm 15,053$, and the data was not normally distributed $(Z=0.169 ; P=0.005)$. A total of 77 elementary level education, with the acquisition of the average value and standard deviation was $51.95 \pm 19.937$, and the data was not normally distributed $(Z=0.129 ; P=0.003)$. In the group of junior high school education level as many as 65 respondents, the acquisition of the average value and standard deviation was $62.46 \pm 17.680$, and the data was not normally distributed $(\mathrm{Z}=0.157 ; \mathrm{P}=0.000)$. The group of high school education level as many as 70 respondents, the acquisition value with the average and standard deviation was $64.00 \pm$ 15,916 , and the data was not normally distributed $(Z=0,233$; $\mathrm{P}=0,000)$.

The homogeneity test results showed the variation of data between sample groups in a homogeneous population $(\mathrm{F}=$ $2,400 ; \mathrm{P}=0,068)$. Then it was analyzed by the Kruskal Wallis test which showed that the status or level of education had an effect on the knowledge of the river ecosystem in lubuk larangan $(\mathrm{X} 2=17.875 ; \mathrm{P}=0.000)$.

The Wilcoxon test showed that the knowledge of river ecosystems in respondents with status as a community $(71.25$ \pm 15.053 ) differed significantly from those with an equivalent elementary school education $(51.95 \pm 19.937)$, junior high school (62.46 \pm 17.680$)$, and senior high school $(64.00 \pm$ 15,916) $(\mathrm{P}=0,000)$.

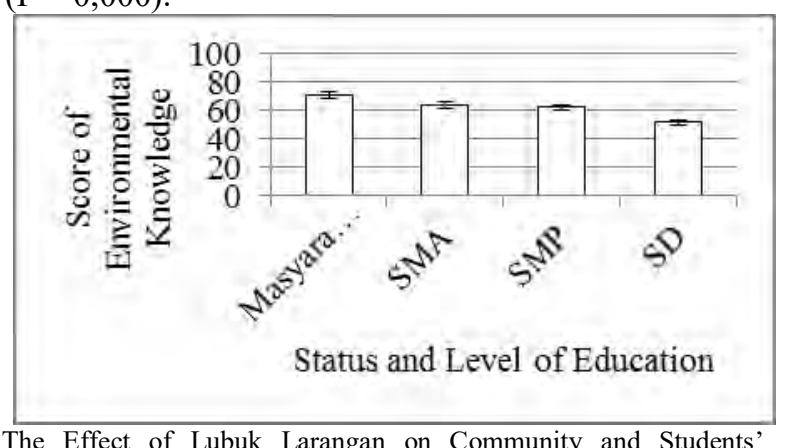

Fig 3. The Effect of Lubuk Larangan on Community and Students' Knowledge Based on Status and Level of Education in Padang Lawas Utara Regency $(\mathrm{P}=0.000)$

\section{DISCUSSION}

Based on the Mann-Whitney test results were obtained $(\mathrm{U}=6144,500 ; \mathrm{P}=0.002)$. Thus, $\mathrm{H}_{0}$ was rejected and $\mathrm{Ha}$ was accepted, so it was concluded that there was a significant effect of lubuk larangan on the knowledge of the community and students based on the school locations in Padang Lawas Utara Regencyt. The school location near lubuk larangan had the highest average compared to the school location which was far from lubuk larangan based on the results obtained from the community and students in Padang Lawas Utara 
Regency. In accordance with the results of the study proved that the atmosphere and conditions of lubuk larangan based on the location near and far from lubuk larangan need to be considered and studied to find out the surrounding environment, because lubuk larangan with a clean environment can make the condition of the Batang Pane river well maintained so as to improve welfare community life. With the existence of a prohibition of the community and students can see and learn directly about the river ecosystem so that it can increase the knowledge of the community and students.

Communities and students who are near lubuk larangan know more, know and interact often than those who are far from lubuk larangan. However, it does not rule out the possibility that the community and students who are far from lubuk larangan has higher knowledge than near lubuk larangan, because the knowledge of lubuk larangan can be obtained from various sources, namely the internet, teachers, and friends.

The results of the study by Harfina (2014) concluded that the location of schools influences the level of knowledge of students. This was supported by a study by Hidayah (2016) which concluded that the location of schools with lubuk larangan had an influence on the level of knowledge about the environment of students in lubuk larangan in Tambangan Jae Village, Tambangan District, Madina Regency. The average knowledge of students who are close to the schools from lubuk larangan is higher than that of students whose schools are far from lubuk larangan.

Based on the Mann Whitney test results were obtained $(\mathrm{U}=6353,000 ; \mathrm{P}=0.014)$. Thus, $\mathrm{H}_{0}$ was accepted and Ha was rejected, so it was concluded that there was a significant effect on the knowledge of the community and students based on a gender perspective in Padang Lawas Utara Regency. A person's knowledge varies based on how a person learns and understands a lesson well and can increase high learning motivation on oneself. The majority of male activities are more outside of women so that natural knowledge is higher in men than in women.

Experience is a major component in improving and expanding knowledge. Knowledge becomes the capital of selfevaluation in reflective thinking. From the evaluation, a belief emerged, both old beliefs and things to do. The level of knowledge between men and women is different, it turns out men have more daily experience to know the depths of prohibition than women.

Based on the results of Kruskal Wallis test was (X2 = 17,875; $\mathrm{P}=0,000)$. Thus, $\mathrm{H}_{0}$ was rejected and $\mathrm{Ha}$ was accepted, so it was concluded that there was a significant effect of lubuk larangan on the knowledge of the community and students based on the level of education in Padang Lawas Utara Regency. The level of education in the community, high school, junior high school and elementary school had a different knowledge about the depth of prohibitions obtained from the community and students. The community in question was parents aged between $35-50$ years who were as many as 5 graduates and 35 non-graduates in Padang Lawas Utara
Regency. The level of education of community knowledge was higher than that of students because the community had understood according to their experience directly about the environment. Maintaining the environment to stay awake requires environmental knowledge to know the impact of good environmental conditions so that it is beneficial for the surrounding community. The community and students have different positive understandings regarding lubuk larangan as one of the river environments that must be maintained properly.

Increasing one's knowledge is closely related to the level of education. The higher the level of education of a person, the higher the knowledge is because more information is obtained to increase knowledge. Different levels of education of community and students can be seen from different knowledge. The higher the level of education influences one's knowledge about the lubuk larangan as a river ecosystem. It is also the community and students must have local wisdom about lubuk larangan that can be developed for the advancement of the surrounding area, because local wisdom is part of the culture of local knowledge that is formed through the learning process by means of observation, testing, and practice that people have (Tamalene et al., 2014) With this learning process, their cultural knowledge increases and understands that lubuk larangan has a positive impact on the welfare of citizens.

Through the implementation of local wisdom education is expected to create an education system that is able to prepare quality human resources and are ready to compete in the global era, but has good character, personality, moral and ethical values. Through local wisdom education, it is expected that regional potential and wealth can be optimally developed for the benefit of the community (Istiawati, 2016).

Based on research by Ramasamy (2013) that the higher the level of education, the better the level of knowledge. This is a relationship between the level of education and the level of knowledge. It is also evident in the results of research by Hidayah (2016) that concluded that the level of education influences the level of knowledge about the student's environment in the local wisdom of lubuk larangan. The average community knowledge is higher than that of high school, middle school and elementary school students.

Sipalanduk's Lubuk Larangan in Padang Lawas Utara Regency has regulations according to customs, including customary law for violations of fishing in lubuk larangan. Various village regulations and customary law were made, so that the survival of the ecosystem occurred in the prohibition. The ban was confirmed in the village regulation No. 01 of 2014 concerning strictly prohibited taking fish or other animals in any way in the lubuk larangan area of Sipalanduk Nagargar. Every person and body or organization that does not comply with the rules will be subject to a fine of $\mathrm{Rp}$. $5,000,000$. If an individual intentionally takes the lubuk larangan fish is not directly subject to the fine, but first is given direction and firm advice so as not to repeat the act that violates the rule. If the individual violates the second rule, then 
the strict rules in the form of a fine will apply without any further direction because there is a mutual agreement.

In South Tapanuli Regency there is the location of Raniate's Lubuk Larangan which has a river in certain parts that have been spread by fish seeds and or indeed there are certain types of fish that can only be taken after a predetermined time after Eid. If there are people who are caught taking the fish outside the time specified, then the fine that reaches millions will be charged, and the fine will go into the typical village.

Lubuak Landua is a lubuk larangan located in West Pasaman Regency which is famous for its prohibited fish. Fish that are in lubuk larangan recently the fish has never been taken. Missively, if someone stole it, they will get sick and even cause death. With the announcement like this, it turns out that no person or community takes fish carelessly and maintains the cleanliness of the environment in lubuk larangan properly. Therefore, maintaining and preserving the environment is a joint obligation to improve the welfare of citizens.

\section{CONCLUSION}

Based on the results of the research and discussion that has been described, some conclusions are obtained as follows: There was the effect of lubuk larangan on the community and students' knowledge based on school locations about the river ecosystem in Padang Lawas Utara Regency $(\mathrm{P}=0.002<0.05)$. There was the effect of lubuk larangan on the community and students' knowledge based on gender perspective about the river ecosystem in Padang Lawas Utara Regency $(\mathrm{P}=0.014$ $<0.05)$. There was the effect of lubuk larangan on the community and students' knowledge based on the level of education about the river ecosystem in Padang Lawas Utara Regency $(\mathrm{P}=0,000<0.05)$.

\section{Acknowledgment}

Acknowledged to the directorate of research and community service, directorate general of strengthening research and development of the ministry of research, technology and higher education, in accordance with the research contract, number: 045a/un33.8/11/2017.

\section{References}

[1] Ardan, A.S. 2016. The Development of Biology Teaching Material Based on the Local Wisdom of Timorese to Improve Students Knowledge and Attitude of Environment In Caring the Persevation of Environment. International Journal of Higher Education, 5(3): 190200.

[2] Ariwidodo, E. 2014. Relevansi Pengetahuan Masyarakat Tentang Lingkungan dan Etika Lingkungan dengan Partisipasinya dalam Pelestarian Lingkungan. Nuansa, 11(1): 1-17.

[3] Fajarini, U. 2014. Peranan Kearifan Lokal dalam Pendidikan Karakter. Sosio Didaktika, 1(2):123-130.

[4] Harfina. 2014. Faktor-Faktor yang Memengaruhi Pengetahuan dan Kepedulian Siswa terhadap Ekosistem Mangrove. Tesis. Tidak
Diterbitkan. Medan: Program Studi Pendidikan Biologi Pascasarjana.Universitas Negeri Medan.

[5] Hidayah, N. 2016. Analisis Pengetahuan Lingkungan dan Sikap Peduli Lingkungan terhadap Ekosistem Sungai Berbasis Kearifan Lokal Lubuk Larangan di Desa Tambangan Jae Kecamatan Tambangan Kabupaten Madina. Tesis (tidak dipublikasikan). Medan: Universitas Negeri Medan.

[6] Istiawati, F.N. 2016. Pendidikan Karakter Berbasis Nilai-Nilai Kearifan Lokal Adat Ammatoa dalam Menumbuhkan Karakter Konservasi. Cendikia, 10(1): 1-18.

[7] Khusniati, M. 2014. Model Pembelajaran Sains Berbasis Kearifan Lokal dalam Menumbuhkan Karakter Konservasi. Indonesian Journal of Conservation, 3(1): 67-74.

[8] Ramasamy, A., dan Lumongga., F. 2013. Hubungan Tingkat Pendidikan dengan Tingkat Pengetahuan Tentang Antenatal Care dalam Kalangan Ibu Usia Subur. Universitas Sumatra Utara. E - Jurnal FK USU, 1(1): 1-5.

[9] Saam, Z., dan Amri, F. 2012. The Local Wisdom of Lubuk Larangan as a Conservation Effort of the Sengingi River. Semarang: Prosiding Seminar Nasional Pengelolaan Sumber Daya Alam dan Lingkungan di UNDIP.

[10] Salim, E. 2006. Alam Terkembang Menjadi Guru. Edisi 5. Majalah Jendela, Informasi dan Komunikasi.

[11] Sanjaya, W. 2014. Strategi Pembelajaran Berorientasi Standar Proses Pendidikan. Jakarta: Kencana Prenada Media Group.

[12] Setyowati, D.L., Sunarko, Rudatin, dan Sedyawati, S.M.R. 2014. Pendidikan Lingkungan Hidup. Semarang: Universitas Negeri Semarang.

[13] Suastra, I.W. 2017. Balinese Local Wisdom and their Implication in Science Education at School. Internatonal Research Journal of Management IT and Social Science (IRJMIS), 4(2): 42-50.

[14] Sugiyo, R., and Purwastuti, A.L. 2017. Local Wisdom-Based Character Education Model in Elementary School in Bantul Yogyakarta Indonesia. Sino-US English Teaching, 4(5): 299-308.

[15] Sugiyono. 2015. Metode Penelitian Pendidikan Pendekatan Kuantitatif, Kualitatif dan $R \& D$. Bandung: Alfabeta.

[16] Susanto, A. 2013. Teori Belajar dan Pembelajaran di Sekolah Dasar. Jakarta: Kencana Prenada Media Group.

[17] Susilawati, Fikriyah, and Saefudin, A. 2015. Science Education Based on Cirebon Local Culinary Food. International Journal of Islamic and Civilizational Studies, 3(3): 42-49.

[18] Tamalene, M.N., Muhdhar, M.H.I.A., Suarsini, E., Rochman, F. 2014. The Practice of Local Wisdom of Tobelo Dalam (Togutil) Tribal Community in Forest Conservation in Halmahera Indonesia. International Journal of Plant Research, 4(4): 1-7.

[19] Tambunan, R.Q., and Laman. 2015. To Manage of Lubuk Larangan As A Environmental Wisdom In Salambue Village Penyabungan City Subdistrict Madina Regency North Sumatera Province. Pusat Penelitian Lingkungan Hidup Universitas Riau, 2(1): 1-7.

[20] Wisudawati, A.W. dan Sulistyowati, E. 2014. Metodologi Pembelajaran IPA. Jakarta: Bumi Aksara. 